\title{
Modification in the xylose absorption test as an index of intestinal function
}

\author{
H. G. SAMMONS, D. B. MORGAN, A. C. FRAZER, R. D. MONTGOMERY, \\ W. M. PHILIP, AND M. J. PHILLIPS \\ From the Departments of Pathology and Medicine and the Metabolic Unit, East Birmingham \\ Hospital, Birmingham, and the Department of Pathology, R.A.F. Hospital, Wroughton
}

COMMENT This paper confirms the fact that a small oral dose of $d$ xylose (5 g.) gives good evidence of small bowel malabsorption when its excretion is followed in the urine. Much better localization of the intestinal defect can be gained by measuring the two-hourly and five-hourly urinary excretion after this dose. A normal five-hour excretion may be accompanied by a lowered two-hourly excretion, thus still indicating the presence of upper small bowel disease.

The fraction of an oral dose of $d(+)$ xylose excreted in the urine in five hours has been widely used as a test of the absorptive capacity of the small intestine (Fourman, 1948; Fowler and Cooke, 1960; Joske and Curnow, 1962; Sheehy and Floch, 1964). In subjects with normal renal function the five-hour urine excretion of xylose after an oral dose depends on four main factors: the stomach emptying time, the rate and duration of absorption of the xylose from the intestinal lumen, and the rate of metabolism of the xylose once absorbed. The rate of absorption depends on the functional integrity of the intestinal mucosa; absorption will continue as long as xylose remains in the small intestine.

The procedure frequently adopted in the study of patients with malabsorption is that of Helmer and Fouts (1937), who gave $25 \mathrm{~g}$. of xylose and measured the xylose in the urine in the following five hours. Unfortunately this large dose of xylose is nauseating and causes diarrhoea in a third of patients (Chanarin and Bennett, 1962) and even, in our experience, in some normal people.

Butterworth, Perez-Santiagio, Martinez de Jesus, and Santini (1959) and Santini, Sheehy, and Martinez de Jesus (1961) found that a $5 \mathrm{~g}$. dose did not cause diarrhoea but still distinguished intestinal disease from normal subjects. Rinaldo and Gluckmann (1964), however, found that this smaller 5g. dose only revealed the more severely affected patients. We have found that with either the 5 or $25 \mathrm{~g}$. dose the test is insensitive in that it fails to distinguish the borderline cases. We felt that variation in the dose of xylose given, or a more careful study of the excretion of xylose, especially in the first five hours, might increase the sensitivity of the test. We have, therefore, investigated xylose excretion after doses ranging from 0.5 to $25 \mathrm{~g}$. and followed the pattern of excretion in the urine. A preliminary account of this work, with a description of a modified xylose excretion test has been published previously (Morgan and Sammons, 1964) and the limitations of this test emphasized (Sammons, 1965). Additional evidence supporting the modified test is now presented together with a more detailed discussion of the concepts involved.

\section{METHODS}

ESTIMATION OF XYLOSE The method of Roe and Rice (1948) was used. One ml. of the test solution was always retained and used as a standard.

TECHNIQUE All subjects were fasted overnight but fluid intake was not restricted and where necessary it was encouraged. This was essential in patients who were dehydrated and in children. A dose of $d(+)$ xylose (B.D.H.) was given in $250 \mathrm{ml}$. distilled water at 9.0 a.m. Solid food, but not fluid, was withheld until a normal meal was given, usually at 2.0 p.m. Urine was collected in timed periods as described in the results. A request for a routine xylose tolerance test after a $5 \mathrm{~g}$. dose now requires that the urine be collected in two consecutive periods of two and three hours' duration. The two-hour and fivehour excretion and the two : five-hour excretion ratio are reported.

NORMAL SUBJECTS These were members of the hospital staff and patients who had no evidence of gastrointestinal disease or impairment of renal function.

PATIENTS WITH ENTEROPATHY The results in 44 subjects 
have been given to illustrate various aspects of the xylose tolerance test. All had a serum urea level less than $50 \mathrm{mg}$. per $100 \mathrm{ml}$. and no proteinuria. Four had gluteninduced enteropathy affecting the upper small intestine with marked steatorrhoea; the creatinine clearance was more than $70 \mathrm{ml} . / \mathrm{min}$. in all of them. Four others had steatorrhoea but a completely normal absorption of xylose, and four had had a partial gastrectomy. Twentyeight patients had a low two-hour and four had a low three-hour excretion. None of these had a disease which primarily affects the upper small intestine but some of them had other evidence suggestive of malabsorption.

TABLE I

TWO- AND FIVE-HOUR XYLOSE EXCRETION IN NORMAL SUBJECTS

\begin{tabular}{ccccccccc} 
Subject & \multicolumn{2}{l}{ Dose $(\mathrm{g})}$. & & & & \\
\cline { 2 - 8 } & $0 \cdot 5$ & $1 \cdot 0$ & $1 \cdot 5$ & $2 \cdot 0$ & $5 \cdot 0$ & $10 \cdot 0$ & $15 \cdot 0$ & $25 \cdot 0^{1}$ \\
\cline { 2 - 8 } & Two-hour & Excretion $(\%$ dose) & & & & & & \\
A & 28 & 29 & 28 & 29 & 22 & 17 & 17 & 13 \\
B & 31 & 24 & 28 & 25 & 28 & 20 & 17 & 13 \\
& 27 & & & & & & & \\
C & 16 & 23 & 26 & 28 & 27 & 15 & 19 & 13 \\
D & 21 & 23 & 21 & 19 & 14 & 13 & 9 & 7 \\
E & 25 & 26 & 19 & 24 & 18 & 17 & 16 & 14 \\
& 26 & & & & & & & \\
Average & 25 & 25 & 25 & 25 & 22 & 16 & 16 & 12
\end{tabular}

\begin{tabular}{ccccccccc}
\multicolumn{2}{c}{ Five-hour } & Excretion $(\%$ dose $)$ & & & & & \\
A & 39 & 33 & 41 & 44 & 33 & 24 & 30 & 27 \\
B & 53 & 42 & 39 & 39 & 45 & 36 & 26 & 26 \\
C & 46 & & & & & & & \\
D & 30 & 38 & 40 & 41 & 40 & 24 & 26 & 24 \\
E & 38 & 34 & 33 & 33 & 28 & 30 & 18 & 22 \\
& 37 & 39 & 32 & 31 & 31 & 30 & 31 & 30
\end{tabular}

$\begin{array}{lllllllll}\text { Average } & 40 & 37 & 37 & 38 & 35 & 29 & 26 & 26\end{array}$

${ }^{1}$ All subjects found the $25 \mathrm{~g}$. dose nauseating and three out of five had diarrhoea afterwards.

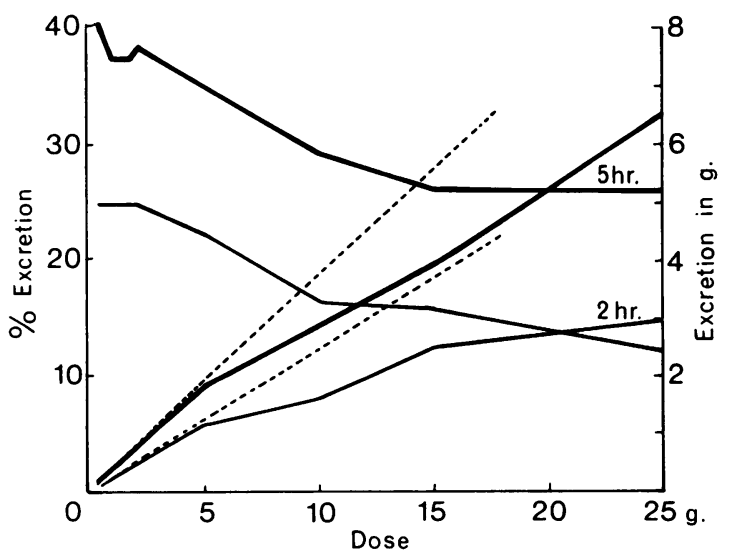

FIG. 1. Pattern of excretion after varying doses in five normal subjects. Dotted lines indicate departures from linearity after $5 \mathrm{~g}$. dose.

\section{RESULTS}

XYLOSE EXCRETION AFTER DIFFERENT DOSES The pattern of excretion in five normal persons after doses varying from 0.5 to $25.0 \mathrm{~g}$. is given in Table I and illustrated diagrammatically in Fig. 1 which also shows the departure from linearity for doses above $5 \mathrm{~g}$. Table I also shows the consistency of the results in these persons.

EXCRETION OF XYLOSE AFTER A 5 G. DOSE Table II shows that after a $5 \mathrm{~g}$. dose in 52 normal subjects the results for the five-hour excretion of xylose are identical with the results reported by others, the mean value being $35 \%$ with a standard deviation of $6 \cdot 2$ and a range of 23 to 48 .

\section{TABLE II}

XYLOSE EXCRETION (\% DOSE) IN NORMAL SUBJECTS USING A 5 G. DOSE

No. of Mean S.D. Minimum Maximum Tests

\begin{tabular}{lrrrrr}
\hline Butterworth et al. (1959) & 29 & 34 & 5 & - & - \\
Santini et al. (1961) & 125 & 36 & 6 & 24 & 48 \\
$\begin{array}{l}\text { Present series } \\
\quad \text { Five-hour }\end{array}$ & 52 & 35 & $6 \cdot 2$ & 23 & 48 \\
$\quad$ Two-hour & 40 & 23 & $4 \cdot 5$ & 14 & 34 \\
Two-hour : five-hour (\%) & 40 & 62 & $10 \cdot 1$ & 39 & 81
\end{tabular}

Table III shows the cumulative excretion of xylose over the 24 hours after a $5 \mathrm{~g}$. dose in 29 tests on 19 normal persons and 10 tests on four patients with gluten-induced enteropathy. The five-hour excretion was similar in the two groups but the patients with gluten-induced enteropathy put out less in the first two hours.

TABLE III

CUMULATIVE XYLOSE EXCRETION OVER 24 HOURS AFTER A 5 G. DOSE

Percentage Dose

\begin{tabular}{|c|c|c|c|c|c|c|}
\hline \multirow[b]{2}{*}{$\begin{array}{l}\text { Time } \\
(h r .)\end{array}$} & \multirow[b]{2}{*}{$\begin{array}{l}\text { No. of } \\
\text { Tests }\end{array}$} & \\
\hline & & Mean & S.D. & Min. & Max. & $\begin{array}{l}\% 24-h o u r \\
\text { Excretion }\end{array}$ \\
\hline \multicolumn{7}{|c|}{ Normal Subjects } \\
\hline 2 & 29 & $22 \cdot 9$ & \pm 4.5 & $14 \cdot 2$ & $29 \cdot 9$ & 54 \\
\hline 5 & 29 & $35 \cdot 7$ & $+7 \cdot 1$ & $22 \cdot 8$ & 47.9 & 84 \\
\hline 8 & 29 & $39 \cdot 0$ & $\pm 7 \cdot 1$ & $23 \cdot 2$ & $51 \cdot 4$ & 92 \\
\hline 12 & 29 & $40 \cdot 7$ & $\pm 7 \cdot 3$ & $24 \cdot 5$ & $52 \cdot 2$ & 96 \\
\hline 24 & 29 & $42 \cdot 5$ & $\pm 8 \cdot 0$ & $25 \cdot 8$ & $53 \cdot 3$ & 100 \\
\hline \multicolumn{7}{|c|}{ Patients with Gluten-induced Enteropathy } \\
\hline 2 & 10 & $6 \cdot 4$ & & $4 \cdot 1$ & $8 \cdot 4$ & $25 \cdot 0$ \\
\hline 5 & 10 & $19 \cdot 0$ & & $13 \cdot 3$ & $26 \cdot 5$ & 75 \\
\hline 8 & 10 & $23 \cdot 1$ & & 16.9 & $32 \cdot 6$ & 92 \\
\hline 12 & 10 & $24 \cdot 4$ & & $17 \cdot 9$ & $34 \cdot 5$ & 96 \\
\hline 24 & 10 & $25 \cdot 3$ & & $18 \cdot 2$ & 35.6 & 100 \\
\hline
\end{tabular}

The excretion of xylose in the first five hours after a dose was studied in more detail. Figure 2 shows the excretion of xylose in each of the first five hours 


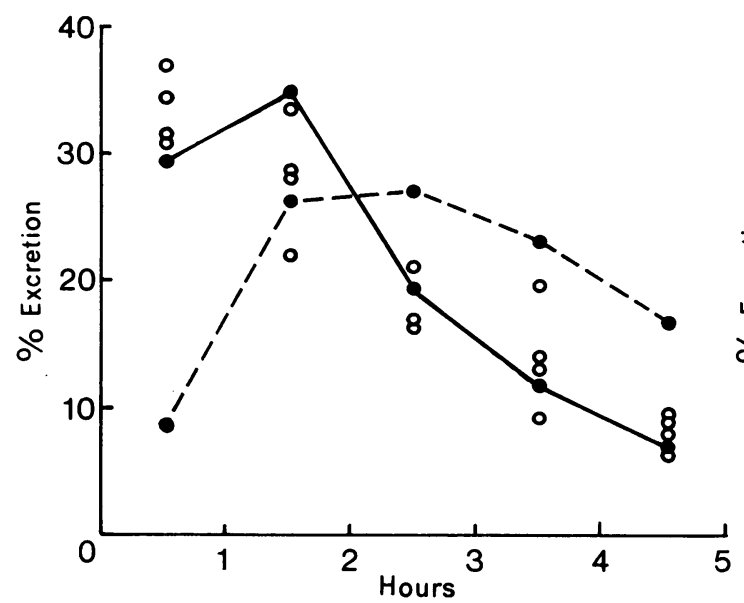

FIG. 2. Hourly excretion of xylose expressed as percentage of total five-hour excretion after $5 \mathrm{~g}$. dose.

Mean values in 16 normal subjects.

-. - Mean of 10 tests on four patients with gluteninduced enteropathy.

(O) Four other patients with partial gastrectomy.

after $5 \mathrm{~g}$. of xylose in 16 normal subjects and in the four patients with gluten-induced enteropathy and in four cases after partial gastrectomy. The excretion in each hour was calculated as a proportion of the total five-hour excretion. The normal subjects put out more than half of the five hours' excretion in the first two hours while the patients with gluteninduced enteropathy put out less than a third of their five hours' excretion in the first two hours (Fig. 3). The maximum excretion of xylose in four patients with partial gastrectomy was in the first hour (Fig. 2) and this would be expected from the rapid entry of the xylose into the small intestine of these patients. On the basis of these results we

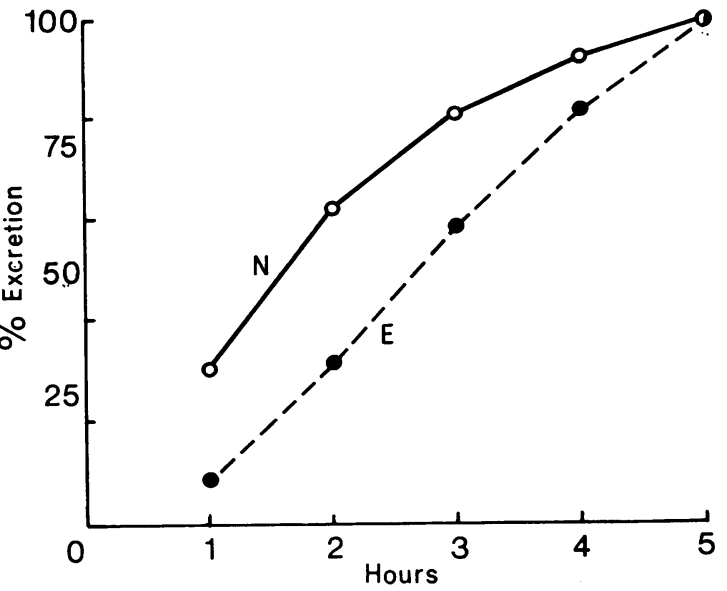

FIG. 3. Cumulative excretion of xylose expressed as percentage of total five-hour excretion after a $5 \mathrm{~g}$. dose in $(N) 16$ normal subjects; $(E)$ in four subjects with gluteninduced enteropathy.

chose to measure the excretion of xylose in consecutive periods of two hours and three hours after a $5 \mathrm{~g}$. dose. Table II also includes the results of the twc-hour excretion and the $2 \mathrm{hr} . / 5 \mathrm{hr}$. ratio in 40 of these normal subjects, the mean value for two hours being $23 \%$ with a standard deviation of 4.5 and a range of 14 to 34 . The mean $2 \mathrm{hr} .: 5 \mathrm{hr}$. percentage ratio is 62 with a standard deviation of $10 \cdot 1$ and a range of 39 to 81 . Table IV shows the reproducibility of this test in one normal person and one patient.

Tables V and VI show the results of this modified xylose excretion test in 32 patients with their clinical and biochemical abnormalities.

Table VII shows the findings in four patients with a normal xylose excretion test in spite of steatorrhoea.

TABLE IV

REPRODUCIBILITY OF TEST

Xylose Excretion (\%) in

\begin{tabular}{lcc} 
& \multicolumn{2}{c}{ Xylose Excretion $(\%)$ in } \\
\cline { 2 - 3 } Day & Two Hours & Five Hours \\
\hline 1 & $22 \cdot 1$ & $31 \cdot 0$ \\
2 & 21.9 & $33 \cdot 7$ \\
3 & $22 \cdot 3$ & $34 \cdot 4$ \\
4 & $24 \cdot 5$ & $35 \cdot 8$ \\
5 & $24 \cdot 5$ & $34 \cdot 1$ \\
6 & $23 \cdot 6$ & $38 \cdot 0$
\end{tabular}

Subject with gluten-induced Enteropathy

\begin{tabular}{|c|c|c|c|c|c|c|c|c|c|c|c|c|c|}
\hline \multirow[b]{2}{*}{ Day } & \multicolumn{7}{|c|}{ Excretion (\%) Dose Xylose } & \multicolumn{6}{|c|}{ Hourly (\%) Five-hour Excretion } \\
\hline & 1 & 2 & 3 & 4 & 5 & $\begin{array}{l}\text { Two-hour } \\
\text { Total }\end{array}$ & $\begin{array}{l}\text { Five-hour } \\
\text { Total }\end{array}$ & 1 & 2 & 3 & 4 & 5 & $2 / 5$ \\
\hline $\begin{array}{l}1 \\
3 \\
5\end{array}$ & $\begin{array}{l}0.9 \\
1.3 \\
0.6\end{array}$ & $\begin{array}{l}4 \cdot 0 \\
5 \cdot 2 \\
3 \cdot 5\end{array}$ & $\begin{array}{l}4 \cdot 7 \\
5 \cdot 5 \\
3 \cdot 1\end{array}$ & $\begin{array}{l}3 \cdot 3 \\
4 \cdot 2 \\
3 \cdot 7\end{array}$ & $\begin{array}{l}2 \cdot 3 \\
2 \cdot 8 \\
2 \cdot 4\end{array}$ & $\begin{array}{l}4 \cdot 9 \\
6 \cdot 5 \\
4 \cdot 1\end{array}$ & $\begin{array}{l}15 \cdot 2 \\
19 \cdot 0 \\
13.3\end{array}$ & $\begin{array}{l}5.9 \\
6 \cdot 8 \\
4 \cdot 5\end{array}$ & $\begin{array}{l}26 \cdot 3 \\
27 \cdot 3 \\
26 \cdot 3\end{array}$ & $\begin{array}{l}30.9 \\
28.9 \\
23.2\end{array}$ & $\begin{array}{l}21 \cdot 7 \\
22 \cdot 1 \\
27 \cdot 8\end{array}$ & $\begin{array}{l}15.1 \\
14.7 \\
18.0\end{array}$ & $\begin{array}{l}32 \cdot 2 \\
34 \cdot 1 \\
30.8\end{array}$ \\
\hline
\end{tabular}


TABLE V

RESULTS OF MODIFIED XYLOSE EXCRETION TESTS IN SELECTED CASES

Case Age Sex Two-hr. Five-hr. 2:5-hr. Faecal Serum Iron Serum Figlu Serum Ba Schilling Haemoglobin

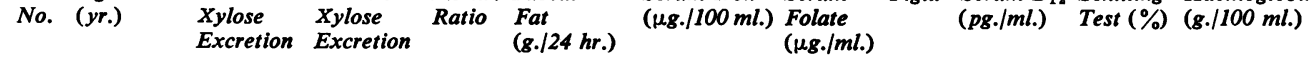

\begin{tabular}{|c|c|c|c|c|c|c|c|c|c|c|c|c|c|}
\hline $\begin{array}{l}1 \\
2\end{array}$ & $\begin{array}{l}56 \\
54\end{array}$ & $\begin{array}{l}\mathbf{F} \\
\mathbf{M}\end{array}$ & $\begin{array}{r}5 \cdot 7 \\
10 \cdot 9\end{array}$ & $\begin{array}{c}30.7 \\
36.2\end{array}$ & $\begin{array}{l}18 \cdot 5 \\
30 \cdot 0\end{array}$ & $\begin{array}{l}6 \cdot 2 \\
1 \cdot 7\end{array}$ & $\overline{58}$ & $\begin{array}{l}1 \cdot 7 \\
-\end{array}$ & $\overline{\text { Pos. }}$ & - & $\begin{array}{r}8.0 \\
-\end{array}$ & $\begin{array}{r}4 \cdot 6 \\
10 \cdot 3\end{array}$ & $\begin{array}{l}\text { Dimorphic anaemia with diarrhoea } \\
\text { Dimorphic anaemia; angular stom- } \\
\text { atitis and glossitis; hiatus hernia }\end{array}$ \\
\hline 3 & 37 & $\mathbf{F}$ & $12 \cdot 8$ & $36 \cdot 8$ & $35 \cdot 0$ & 11.0 & 26 & - & Pos. & 100 & - & $9 \cdot 6$ & $\begin{array}{l}\text { Dimorphic anaemia; steatorrhoea; } \\
\text { markedly dilated duodenum on } \\
x \text {-ray; ? cause }\end{array}$ \\
\hline 4 & 37 & $\mathbf{F}$ & $10 \cdot 8$ & 29.0 & $37 \cdot 0$ & 3.0 & 50 & 1.7 & Neg. & 269 & - & $10 \cdot 9$ & $\begin{array}{l}\text { Dimorphic anaemia; buccal ulcer- } \\
\text { ation; stool nitrogen } 3-5 \text { g. per day }\end{array}$ \\
\hline 5 & 16 & $\mathbf{M}$ & 11.9 & 29.5 & $40 \cdot 0$ & 3.7 & 52 & $4 \cdot 5$ & - & - & - & 9.5 & $\begin{array}{l}\text { Iron-deficiency anaemia; slight dil- } \\
\text { atation of the ileum; occult blood } \\
\text { loss }\end{array}$ \\
\hline $\begin{array}{l}6 \\
7\end{array}$ & $\begin{array}{l}38 \\
43\end{array}$ & $\begin{array}{l}\mathbf{F} \\
\mathbf{F}\end{array}$ & $\begin{array}{r}10 \cdot 8 \\
8 \cdot 0 \\
21 \cdot 4\end{array}$ & $\begin{array}{l}39 \cdot 0 \\
28 \cdot 0 \\
31 \cdot 8\end{array}$ & $\begin{array}{l}28 \cdot 0 \\
29 \cdot 0 \\
62 \cdot 0\end{array}$ & $\overline{-}$ & $\begin{array}{l}69 \\
60\end{array}$ & - & - & -243 & - & $\begin{array}{r}6 \cdot 8 \\
9 \cdot 0 \\
11 \cdot 4\end{array}$ & $\begin{array}{l}\text { Iron-deficiency anaemia } \\
\text { Iron-deficiency anaemia; occult } \\
\text { blood loss }\end{array}$ \\
\hline
\end{tabular}

\section{After oral iron treatment}

$8 \quad 16 \mathrm{M} \quad 12 \cdot 0$

$\begin{array}{llll}9 & 47 & M & 13.0\end{array}$

$\begin{array}{llll}10 & 61 & F & 7 \cdot 0\end{array}$

$\begin{array}{llll}11 & 61 & F & 10.9\end{array}$

$30.0 \quad 40.0$

-

$\begin{array}{ll}32 \cdot 0 & 22 \cdot 0 \\ 29 \cdot 8 & 37 \cdot 0\end{array}$

$\overline{1.6}$

$1 \cdot 6$

$\begin{array}{lll}34 & 0.5 & - \\ - & - & -\end{array}$

-10
79
90

$\begin{array}{rr}- & 8.9 \\ 1.9 & 7.9 \\ 0.4 & 2.3 \\ 13.3 & 4.5\end{array}$

$8 \cdot 9$
$7 \cdot 9$

Jejunitis (operative finding)

Addisonian anaemia

Addisonian anaemia; diarrhoea

Epilepsy; megaloblastic anaemia due to mysoline

$\begin{array}{llllllll}2.2 & 145 & 4.3 & - & 1,000 & - & 5.8 & \text { Subacute monoblastic leukaemia }\end{array}$

(patient died at home).

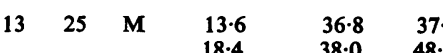

$\mathbf{8 \cdot 1}$

65

$9 \cdot 7$
$14 \cdot 7$

Duodenal ulcer; mild steatorrhoea

14.7 Occult blood loss; complete re-

covery on medical treatment

\begin{tabular}{|c|c|c|c|c|c|c|c|c|c|c|c|c|}
\hline \\
\hline \multicolumn{13}{|c|}{$\begin{array}{l}\text { After treatment } \\
14 \quad 55 \quad M\end{array}$} \\
\hline 15 & 58 & $\mathbf{M}$ & $11 \cdot 6$ & $37 \cdot 0$ & $31 \cdot 0$ & $10 \cdot 0$ & 116 & - & Pos. & - & - & $13 \cdot 2$ \\
\hline 16 & 38 & $\mathbf{F}$ & 10.0 & $40 \cdot 0$ & $25 \cdot 0$ & - & - & $2 \cdot 3$ & - & - & - & $12 \cdot 8$ \\
\hline 17 & 59 & $\mathbf{M}$ & 10.7 & $29 \cdot 1$ & $37 \cdot 0$ & 3.0 & - & - & - & 265 & - & 13.0 \\
\hline 18 & 21 & $\mathbf{F}$ & $13 \cdot 7$ & $32 \cdot 4$ & $42 \cdot 0$ & $2 \cdot 7$ & 40 & $4 \cdot 7$ & - & 172 & - & $12 \cdot 3$ \\
\hline 19 & 21 & $\mathbf{F}$ & $10 \cdot 0$ & $28 \cdot 0$ & 36.0 & $5 \cdot 4$ & 34 & 0.6 & - & - & - & 9.8 \\
\hline 20 & 39 & $\mathbf{F}$ & $13 \cdot 0$ & 33.0 & 39.0 & - & 28 & $3 \cdot 0$ & - & 273 & - & $10 \cdot 1$ \\
\hline 21 & 22 & $\mathbf{M}$ & 9.0 & 33.4 & $27 \cdot 0$ & 6.5 & 80 & - & Pos. & 595 & - & 13.0 \\
\hline 22 & 28 & $\mathbf{M}$ & $11 \cdot 4$ & $31 \cdot 1$ & $37 \cdot 0$ & $3 \cdot 0$ & - & - & Pos. & 507 & - & $14 \cdot 0$ \\
\hline 23 & 12 & $\mathbf{M}$ & $13 \cdot 2$ & $29 \cdot 7$ & $45 \cdot 0$ & $8 \cdot 0$ & 一 & - & - & - & 一 & 一 \\
\hline 24 & 63 & $\mathbf{F}$ & $11 \cdot 5$ & $28 \cdot 1$ & $40 \cdot 1$ & $7 \cdot 0$ & - & Low & Neg. & 217 & - & $12 \cdot 3$ \\
\hline 25 & 59 & $\mathbf{M}$ & $9 \cdot 9$ & $33 \cdot 4$ & $30 \cdot 0$ & $3 \cdot 0$ & - & - & Neg. & - & - & $14 \cdot 3$ \\
\hline 26 & 21 & $\mathbf{M}$ & $10 \cdot 2$ & $29 \cdot 9$ & 52.0 & $4 \cdot 5$ & 30 & - & - & - & - & $9 \cdot 6$ \\
\hline 27 & 23 & $\mathbf{F}$ & $4 \cdot 8$ & $28 \cdot 0$ & $20 \cdot 0$ & - & - & 一 & Pos. & 85 & 一 & $10 \cdot 8$ \\
\hline 28 & 59 & $\mathbf{M}$ & 9.8 & $29 \cdot 2$ & $38 \cdot 5$ & $12 \cdot 6$ & - & - & - & - & - & \\
\hline
\end{tabular}

TABLE VI

Post-gastrectomy malabsorption

Osteomalacia, post-gastrectomy malabsorption

Chronic ulcerative colitis, distal

Chronic ulcerative colitis, distal

Acute ulcerative colitis, total

Acute uicerative colitis, total

Acute ulcerative colitis, distal

Pityriasis rubra pilaris

Hypogammaglobulinaemia ; diarrhoea

Hypogammaglobulinaemia ; steatorrhoea

Hypoproteinaemia; mild steatorrhoea

Osteoporosis (stool nitrogen 2-3 g. per day)

Crohn's disease, lower ileum

Crohn's disease ileum and caecum; fistulae; megaloblastic anaemia

Crohn's disease, ileum

Hypoproteinaemia, wasting ; partial

villous atrophy of upper jejunum

RESULTS OF XYLOSE EXCRETION TESTS IN FOUR SUBJECTS

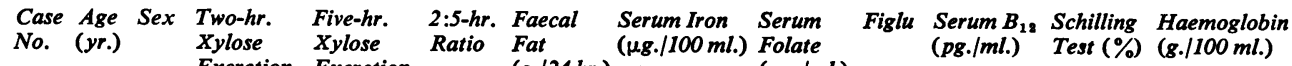
Excretion Excretion (g./24hr.)

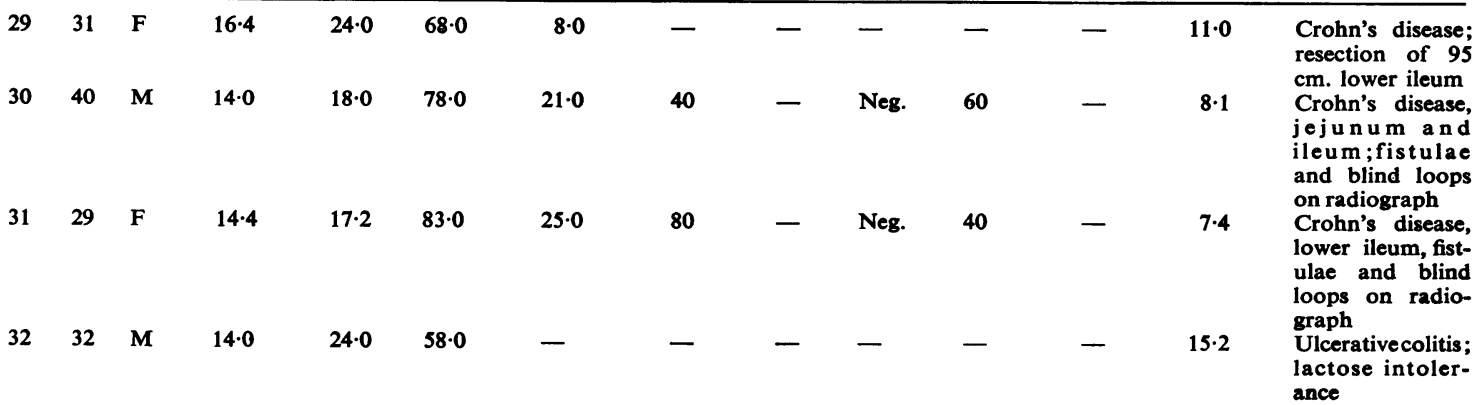


TABLE VII

CASES WITH NORMAL XYLOSE TEST BUT ABNORMAL FAECAL FAT

\begin{tabular}{|c|c|c|c|c|c|}
\hline \multirow[b]{2}{*}{$\begin{array}{l}\text { Case } \\
\text { No. }\end{array}$} & \multicolumn{3}{|c|}{ Xylose Excretion } & \multirow[b]{2}{*}{$\begin{array}{l}\text { Faecal } \\
\text { Fat }(g .)\end{array}$} & \multirow[b]{2}{*}{ Diagnosis } \\
\hline & $T w o-h r$ & Five-hr. & 2:5 Ratio & & \\
\hline 33 & 20.9 & $35 \cdot 8$ & 58 & 10 & $\begin{array}{l}\text { Crohn's disease term- } \\
\text { inal ileum }\end{array}$ \\
\hline 34 & $20 \cdot 1$ & $35 \cdot 6$ & 57 & 8 & $\begin{array}{l}\text { Crohn's disease lower } \\
\text { jejunum, ileum, and } \\
\text { colon }\end{array}$ \\
\hline 35 & $17 \cdot 2$ & $32 \cdot 8$ & 54 & 50 & $\begin{array}{l}\text { Crohn's disease, } \\
\text { ileum; protein-losing } \\
\text { enteropathy }\end{array}$ \\
\hline 36 & $18 \cdot 2$ & $43 \cdot 2$ & 42 & 15 & $\begin{array}{l}\text { Carcinoma of caecum; } \\
\text { subacute obstruction }\end{array}$ \\
\hline
\end{tabular}

DISCUSSION

RELATIONSHIP BETWEEN DOSE AND EXCRETION OF XYLOSE The amount of xylose excreted in five hours increased as the dose increased. There was a linear relationship between the dose given and the amount excreted for the lower doses up to 5 g. (Fig. 1). When the large doses are used the percentage of dose excreted is smaller. This deviation from linearity was evident for the two-hour and five-hour excretions.

The mean five-hour excretion after $25 \mathrm{~g}$. was $25 \%$ which is very close to the values for normal subjects recorded in the literature (Sheehy and Floch, 1964). When this same dose is given intravenously to normal subjects about $40 \%$ is excreted in the urine in five hours (Fourman, 1948; Butterworth et at., 1959) and this suggests that the absorption of a $25 \mathrm{~g}$. dose is incomplete, even in normal subjects. The mean value for the five-hour excretion after a $5 \mathrm{~g}$. dose was $36 \%$ which also agrees closely with the literature (Table II). Two subjects given $5 \mathrm{~g}$. intravenously excreted 40 and $41 \%$ of the dose in five hours, suggesting that absorption of this smaller dose is complete. Complete absorption would explain the absence of intestinal disturbances when this dose is used; incomplete absorption would explain the diarrhoea which follows a $25 \mathrm{~g}$. dose.

The irregular occurrence of diarrhoea after a $25 \mathrm{~g}$. dose (Benson, Culver, Ragland, Jones, Drummey, and Bougas, 1957; Chanarin and Bennett, 1962) could account for the wide variation in results reported in normal subjects and the difficulty in defining the lowest result which can be accepted as normal. A dose of $5 \mathrm{~g}$., however, gives reproducible results in normal and abnormal subjects (Tables IVa and IVb).

Finally, it is worth pointing out that this dose of 5 g. can be used successfully in children (Hubble and Littlejohn, 1963) and in our experience it does not cause diarrhoea, even in the smallest child.
PATTERNS OF EXCRETION In normal subjects most of the five-hour excretion was in the first two hours (Fig. 3). The lower limit of normal would appear to be $14 \%$ excretion in two hours or approximately 23-2 S.D. In patients with enteropathy most of the five-hour excretion was in the last three hours. The difference in the pattern of excretion could be explained by faulty absorption from the small intestine. This may or may not be influenced by stomach emptying time. The delay in excretion in the patients with intestinal disease could be due entirely to delay in stomach emptying, but since the xylose was always given as a water solution after an overnight fast and as there was no radiological evidence of slow stomach emptying in any of the subjects who were radiographed this explanation would seem unlikely.

The amount of xylose absorbed from the intestine depends on the rate of absorption and the duration of absorption; and the rate of excretion depends on the blood level (Wyngaarden, Segal, and Foley, 1957). Maximum excretion, like the maximum concentration of xylose in blood (Thaysen and Müllertz, 1962), is achieved in two hours and absorption is probably complete in this time in the normal person (McCance and Madders, 1930). The later excretion of xylose represents clearance of previously absorbed xylose. The slow two-hour excretion of the patients with enteropathy differentiates them from normal subjects and implies that in such patients there is a slower rate of absorption (Fig. 3). That the five-hour figure was normal in nearly all of these selected patients shows that prolonged absorption at this slower rate resulted in nearly complete absorption. The process of absorption is illustrated diagrammatically in Figure 4. The accumulation of xylose in the body can be represented in normal subjects by line $\mathrm{A}$. When

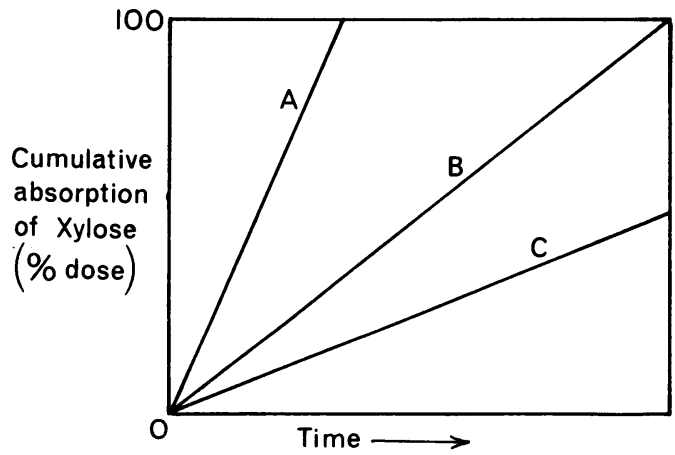

FIG. 4. Process of absorption illustrated diagrammatically. The time axis represents the time during which absorption can occur from the small intestine. For explanation of lines $A, B$, and $C$, see text. 
damage to the intestine is gross the rate of absorption will be slow and absorption prolonged but xylose will leave the small intestine before absorption is complete, and therefore the five-hour excretion will be less than normal (line $C$ ). The degree of damage, however, could be such that although absorption is slow it will continue until all the xylose is absorbed (line B). There is obviously a limit to the time for which absorption can continue since the xylose will eventually leave the small intestine. The longest time is probably not more than five hours in the absence of obstruction and during that time if the amount of xylose absorbed per unit time were constant the accumulation of xylose in blood and urine would be linear (Fig. 1). The minimum value for the fraction of the five-hour excretion occurring in the first two hours would then be about $20 \%$ (Fig. 4, line B) and a value less than this would indicate that there was considerable delay in the stomach emptying, so that only a small fraction of the xylose was available for absorption.

These considerations form the theoretical basis of the modified xylose excretion tests, which included measurement of the two-hour and five-hour excretion and calculation of the two-hour to fivehour excretion ratio. With this modification, impairment of xylose absorption was demonstrated in 28 cases (Table V) even when the total five-hour xylose absorption was normal. In some of these cases there were other abnormalities suggestive of malabsorption. This supports the view that the low two-hour excretion of xylose is usually (if not always) attributable to upper intestinal malabsorption rather than delayed stomach emptying.

In most cases the abnormality of xylose absorption would have been detected by measurement of the two-hour excretion alone, but occasionally accurate interpretation depended on the five-hour excretion as well. In patients $29,30,31$, and 32 (Table VI) the excretion and therefore the absorption of xylose in the first two hours was normal or nearly normal but little more was excreted in the following three hours and the five-hour figure was below normal. This suggested that only the uppermost part of the intestine was intact and able to absorb xylose whereas the lower intestine was diseased. All four patients had a disorder affecting the lower intestine. In these cases another explanation might be the metabolism of xylose by intestinal bacteria in the lower small bowel. However, we consider this improbable as we have been able to show, in a collaborative experiment with Dr. Bridgwater, that incubation of a $2 \%(w / v)$ solution of xylose in peptone broth with nine different strains of xylose-fermenting intestinal bacteria failed to destroy any xylose in five hours and only a maximum of $12 \%$ in 24 hours.

We have not considered in this paper the great majority of patients in whom steatorrhoea correlates with impaired xylose excretion both at two hours and five hours. We have, however, encountered four patients (Table VII) with steatorrhoea whose xylose absorption by all our criteria was normal, a result which suggested that the steatorrhoea was due to a disease confined to the most distal small intestine.

These last cases illustrate that a normal xylose excretion pattern does not entirely exclude malabsorption. We believe nevertheless that it is a useful screening test and is rendered more sensitive by the procedure we have recommended.

\section{REFERENCES}

Benson, J. A., Jr., Culver, P. J., Ragland, S., Jones, C. M., Drummay, G. D., and Bougas, E. (1957). The $d$-xylose absorption test in malabsorption syndromes. New Engl. J. Med., 256, 335-339.

Butterworth, C. E., Jr., Perez-Santiago, E., Martinez de Jesus, J., and Santini, R. (1959). Studies on the oral and parenteral administration of $d(+)$ xylose. Ibid., 261, 157-164.

Chanarin, I., and Bennett, M. C. (1962). Absorption of folic acid and $d$-xylose as tests of small-intestinal function. Brit. med. J., 1 , 985-989.

Fourman, L. P. R. (1948). The absorption of xylose in steatorrhoea. Clin. Sci., 6, 289-294.

Fowler, D., and Cooke, W. T. (1960). Diagnostic significance of $d$-xylose excretion test. Gut, 1, 67-70.

Helmer, O. M., and Fouts, P. J. (1937). Gastro-intestinal studies. VII. The excretion of xylose in pernicious anemia. J. clin. Invest., 16, 343-349.

Hubble, D., and Littlejohn, S. (1963). The $d$-xylose excretion test in coeliac disease in childhood. Arch. Dis. Child., 38, 476-480.

Joske, R. A., and Curnow, D. H. (1962). The $d$-xylose absorption test. Aust. Ann. Med., 11, 4-14.

McCance, R. A., and Madders, K. (1930). The comparative rates of absorption of sugars from the human intestine. Biochem. J., 24, 795-804.

Morgan, D. B., and Sammons, H. G. (1964). A study of small intestinal function using a modification of the xylose tolerance test. Proc. Ass. clin. Biochem., 3, 146-147.

Rinaldo, J. A., Jr., and Gluckmann, R. F. (1964). Maximal absorption capacity for xylose in nontropical sprue. Gastroenterology, 47, 248-250.

Roe, J. H., and Rice, E. W. (1948). A photometric method for the determination of free pentoses in animal tissues. J. biol. Chem., 173, 507-512.

Sammons, H. G. (1965). Limitations of some intestinal function tests. (Abstr.) Gut, 6, 205.

Santini, R., Jr., Sheehy, T. W., and Martinez de Jesus, J. (1961). The xylose tolerance test with a 5-gm. dose. Gastroenterology, 40, 772-774.

Sheehy, T. W., and Floch, M. H. (1964). The Small Intestine, p. 52. Harper and Row, New York.

Thaysen, E. H., and Müllertz, S. (1962). The $d$-xylose absorption tolerance test. Acta med. scand., 171, 521-529.

Wyngaarden, J. B., Segal, S., and Foley, J. B. (1957). Physiological disposition and metabolic fate of infused pentoses in man. J. clin. Invest., 36, 1395-1407. 
However, differential thermostability is the most valuable method for identifying enzyme patterns at the clinical level.

'Dunne, J., Fennelly, J. J., and McGeeney, K. (1967). Cancer (Philad.), $20,1$.

'Posen, S., Neale, F. C., Chubb, J. S. (1965). Ann. intern. Med., 62, 6. 'Wilkinson, J. H. Colston Research Society-Liver Diseases, 1967To be published. Butterworth Scientific Publications.

\section{TREATMENT OF CHRONIC INTRAHEPATIC CHOLESTASIS WITH PHENOBARBITONE}

R. P. H. THOMPSON AND ROGER WILLIAMS (King's College Hospital, London) Four patients with chronic intrahepatic cholestasis have been treated for one to two months with oral phenobarbitone, $90-180 \mathrm{mg}$. per day, without changing their previous treatment. Liver biopsies had shown the appearances of primary biliary cirrhosis in three and of postnecrotic cirrhosis in one. All had had constant plasma bilirubin levels for at least six months, with itching.

Plasma total and direct-reacting bilirubin levels were measured two to three times weekly by the Michaelis method. About four days after starting treatment these levels fell by 40 to $50 \%$, and levelled off at about the tenth day. The proportion of direct-reacting bilirubin rose. All patients noticed less itching and improved wellbeing, and they and their relatives commented on decreased jaundice. Side effects were limited to drowsiness, controlled by reducing the dose.

The mechanism of this reduction of plasma bilirubin levels may be related to the known induction by phenobarbitone of microsomal detoxicating enzymes in animals, in particular glucuronyl transferase. A similar reduction of serum bilirubin levels has been reported by other workers in three patients with unconjugated hyperbilirubinaemia in whom the activity of glucuronyl transferase is low. In the present patients with conjugated hyperbilirubinaemia the plasma level may fall as a result of increased uptake into the liver. The rise in the proportion of direct reacting bilirubin suggests an increased regurgitation into the blood, and the possibility of this and other mechanisms will be discussed.

CORRECTION

In Table $V$ of the paper by H. G. Sammons et al. ('Modification in the xylose absorption test as an index of intestinal function', Gut, 8, 348) there two should be readings for cases 7 and 13, namely, the words, 'After oral iron treatment', refer to the second set of figures for case 7, and the words, 'After treatment', refer to the second set of figures for Case 13. The Table as originally published is misleading. 